\title{
Rejection of Lactobacillus panis (Wiese et al. 1996) Request for an Opinion
}

\author{
FRANCO DELLAGLIO ${ }^{1}$ AND GÜNTER KLEIN ${ }^{2 *}$ \\ Istituto Policattedra, Facoltà di Scienze, Università degli Studi di Verona, 37134 Verona, Italy, ${ }^{1}$ and Institute of Meat \\ Hygiene and Technology, Veterinary Faculty, Free University of Berlin, 14195 Berlin, Germany ${ }^{2}$
}

\begin{abstract}
Lactobacillus panis (Wiese et al. 1996) has not been validly published because type strain DSM 6035 is not available from any culture collection. The lack of an available type strain is not consistent with Principle 1 of the International Code of Nomenclature of Bacteria: Bacteriological Code and may cause confusion if taxonomists are not able to compare new Lactobacillus isolates with an $L$. panis type strain. We request an opinion which indicates whether the name $L$. panis should be rejected. In addition, on behalf of the Subcommittee on Taxonomy of Bifidobacterium, Lactobacillus, and Related Organisms, we strongly support an emendation of Rule 30 of the Bacteriological Code proposed by the Judicial Commission of the International Committee on Systematic Bacteriology in Jerusalem in 1996. This emendation would make mandatory the availability of a type strain of a new species from a culture collection and thus would prevent descriptions of invalidly published species.
\end{abstract}

Wiese et al. (5) recently described a new Lactobacillus species from sourdough, Lactobacillus panis. They designated strain DSM 6035 the type strain. The Subcommittee on Taxonomy of Bifidobacterium, Lactobacillus, and Related Organisms of the International Committee on Systematic Bacteriology (ICSB) realized at its closed meeting in Budapest, Hungary, in August 1996 that the designated type strain of $L$. panis is not available for research purposes. The strain has been deposited in the closed collection of the Deutsche Sammlung von Mikroorganismen und Zellkulturen, Braunschweig, Germany. It is not available for taxonomic investigations and is not available from any other source.

L. panis was not published in accordance with Recommendation 30a of the International Code of Nomenclature of Bacteria: Bacteriological Code because a type strain is not available. Nevertheless, it is not possible to reject the name because of this. General Consideration 6 of the Bacteriological Code (4) states that recommendations do not have the force of rules. In the meantime, the Judicial Commission of the ICSB recommended to the ICSB that Rule 30 should be amended so that availability of a type strain of a new species from a culture collection is mandatory (1). However, so far the recommending character of Recommendation $30 \mathrm{a}$ is in force.

On the other hand, it is evident that if a new Lactobacillus strain that is not similar to any other Lactobacillus strain is isolated, comparison with $L$. panis will not be possible. It is possible that a new species which is identical to L. panis will be validly published. Therefore, the publication of $L$. panis will cause confusion until the type strain is available for taxonomic comparisons. Thus, the lack of an available type strain is not consistent with Principle 1 of the Bacteriological Code (4). We

* Corresponding author. Mailing address: Institute of Meat Hygiene and Technology, Veterinary Faculty, Free University of Berlin, Brümmerstr. 10, D-14195 Berlin (Dahlem), Germany. Phone: 49-30-8382793. Fax: 49-30-838-2792. therefore request an opinion which rejects the name $L$. panis and places it on the list of rejected names (nomina rejicienda). According to Rule 56a of the Bacteriological Code (4), L. panis is a nomen confusum or a nomen dubium because a new species could be identical to $L$. panis. Besides, it is generally accepted in the scientific community $(2,3)$ that a type strain of a new species must be both deposited and readily available.

Labeda et al. (2) and Murray (3) focused on the same problem. As a result, Murray (3) proposed emendation of Rule 30 to include the essential elements of Recommendation 30a. The Judicial Commission of the ICSB accepted this proposal (1).

The members of the Subcommittee on Taxonomy of Bifidobacterium, Lactobacillus, and Related Organisms concluded in Budapest, Hungary, that L. panis is not a validly published name. This statement is still true if Rule 30 is not amended as proposed, because the description is not consistent with Principle 1 of the Bacteriological Code (4). However, on behalf of the subcommittee we strongly support the emendation of Rule 30 proposed by Murray (3) and accepted by the Judicial Commission (1). To avoid confusion in the future, it is advisable to emend Rule 30 to clarify the requirements for descriptions of new species.

\section{REFERENCES}

1. Labeda, D. P. 1997. Judicial Commission of the International Committee on Systematic Bacteriology, VIIIth International Congress of Microbiology and Applied Bacteriology, minutes of the meetings, 17 and 22 August 1996, Jerusalem, Israel. Int. J. Syst. Bacteriol. 47:240-241.

2. Labeda, D. P., C. P. Kurtzman, and J. L. Swezey. 1995. Taxonomic note: use of patent strains as type strains in the valid description of new microbial taxa Int. J. Syst. Bacteriol, 45:868-869.

3. Murray, R. G. E. 1996. Taxonomic note: a rule about the deposition of type strains. Int. J. Syst. Bacteriol. 46:831.

4. Sneath, P. H. A. (ed.). 1992. International code of nomenclature of bacteria: bacteriological code. 1990 revision. American Society for Microbiology, Washington, D.C.

5. Wiese, B. G., W. Strohmar, F. A. Rainey, and H. Diekmann. 1996. Lactobacillus panis sp. nov., from sourdough with a long fermentation period. Int. J. Syst. Bacteriol. 46:449-453. 